A N N A L E S

UNIVERSITATIS M A R I A E C URIE-SKŁODOW S K A

LUBLIN - POLONIA

VOL. XXXI, 2

SECTIO J

2018

Uniwersytet Marii Curie-Skłodowskiej w Lublinie. Wydział Pedagogiki i Psychologii

\title{
BARBARA KALINOWSKA-WITEK
}

ORCID: 0000-0002-4417-1675

barbara.kalinowska-witek@poczta.umcs.lublin.pl

\section{Promocja zdrowia i prawidlowego rozwoju psychofizycznego dziewczat na łamach czasopism kobiecych $z$ drugiej połowy XIX i początków XX w.}

Promotion of Health and Proper Psychophysical Development of Girls on Columns of Woman's Magazines in the Second Half of the $19^{\text {th }}$ and the Beginning of the $20^{\text {th }}$ Centuries

\section{STRESZCZENIE}

Zdrowie jest podstawowym dobrem człowieka. Troska o prawidłowy rozwój potomstwa spoczywa na rodzicach. To oni dostarczają dziecku pożywienie, dbają o właściwy ubiór, organizują czas wolny. Ponadto przekazują synowi i córce określone wartości i przekonania związane ze zdrowiem. W drugiej połowie XIX w. w wielu średniozamożnych rodzinach kierowano się w tej sprawie konwenansem i opinią publiczną, a nie rzetelną wiedzą i zdrowym rozsądkiem. Rodzice przyjmowali niewłaściwe postawy, zwłaszcza w stosunku do córek. Dlatego publicyści czasopism, w trosce o zdrowie dziewcząt - przyszłych matek, krytykowali niewłaściwe podejście do ich wychowania. W celu poznania opinii publicystów na temat błędów rodziców w wychowaniu córek autorka przeprowadziła kwerendę biblioteczną kilku czasopism, m.in. takich jak: „Bluszcz”, „Tygodnik Mód i Powieści”, „Dobra Gospodyni”. Autorzy analizowanych publikacji nie skupiali się jedynie na krytyce niewłaściwych zachowań, ale też podawali wskazówki, jak postępować, aby wspomagać prawidłowy rozwój dziewcząt.

Słowa kluczowe: wychowanie dziewcząt na przełomie XIX i XX w.; błędy wychowawcze rodziców; rozwój fizyczny dziewcząt 


\section{WPROWADZENIE}

W drugiej połowie XIX w. w czasopismach pedagogicznych i tych kierowanych do rodzin niejednokrotnie podkreślano, że obowiązkiem rodziców jest odpowiednie wychowanie młodego pokolenia. W dobie zaborów w dobrej kondycji fizycznej obywateli upatrywano gwarancji przetrwania narodu, a w przyszłości efektywnej pracy dla dobra niepodległego państwa. Troska o zdrowie dzieci i młodzieży należała do zadań rodziców, a zwłaszcza matek, gdyż szkoły znajdujące się pod kontrolą władz zaborczych nie mogły swobodnie realizować nie tylko funkcji dydaktycznych, ale też opiekuńczo-wychowawczych. Niestety, kobiety nie zawsze były odpowiednio przygotowane do wypełniania zadań rodzicielskich. Dlatego redakcje czasopism i publicyści postawili sobie za cel uświadamianie kobietom ich obowiązków, jednocześnie zwracając uwagę na czyhające pułapki i błędne postawy wobec potomstwa. W dyskusję na łamach prasy włączały się także czytelniczki, prezentując swoje poglądy na omawiane kwestie.

Wiele artykułów zamieszczonych w czasopismach pedagogicznych, kobiecych i rodzinnych dotyczy problematyki rozwoju fizycznego oraz zdrowia dzieci i młodzieży, szczególnie dziewcząt - przyszłych matek i wychowawczyń następnych pokoleń. Przestrzegano przed niewłaściwym ubieraniem dziewczynek, rezygnacją ze zdrowego pożywienia na rzecz jego wykwintności, wyrabianiem u córek zamiłowania do uczt i zabaw, brakiem uświadomienia seksualnego młodych kobiet itp. Publicyści starali się uświadomić rodzicom skutki braku odpowiedniego oddziaływania na młode pokolenie, podawali również przykłady mogące stanowić wzór do naśladowania.

\section{BŁĘDY RODZICÓW W ZAKRESIE ŻYWIENIA NIEMOWLĄT I MAŁYCH DZIECI}

W latach 80. XIX w. w wielu czasopismach kierowanych do kobiet ze średnich warstw społecznych podkreślano, jak ważna dla dalszego prawidłowego rozwoju dziecka jest jego właściwa pielęgnacja już od pierwszych chwil życia oraz odpowiednie żywienie. W „Bluszczu” przekonywano czytelniczki, że szczególnie istotny jest pierwszy rok życia dziecka, gdyż:

(...) od wzrostu i zdrowia jego w tym czasie zależy przyszłość jego tak pod względem fizycznym, jak i umysłowym. Szkoda, jaką się wyrządza dziecku przez niedostateczne pielęgnowanie go w pierwszym roku życia lub przez rozmaite choroby, nie da się nigdy wynagrodzić w późniejszych latach (Wiadomości z medycyny(...) 1880, s. 104).

Dr Gustaw Fritsche (1880, s. 119) zalecał, aby karmienie niemowląt odbywało się najlepiej sześć razy dziennie. Na łamach „Świtu” podkreślano, że najwła- 
ściwszym pokarmem jest dla dziecka mleko matki, dlatego kobiety nie powinny $\mathrm{z}$ błahych powodów rezygnować $\mathrm{z}$ tego obowiązku:

(...) ileż to matek, zwłaszcza w wyższych sferach społeczeństwa, uchyla się od tej świętej powinności! Niektóre czynią to z lekkomyślności, z chęci nieopuszczania zabaw i światowego trybu życia; inne - przez źle zrozumianą troskliwość o swą piękność, inne zaś - a tych jest najwięcej - bo im nikt nie zwrócił uwagi na ważność tego zaniedbania i tej winy (Jarosław 1885, s. 103).

Powołując się na opinię francuskiego lekarza dra Juliusza Brocharda, jeden z publicystów przestrzegał młode matki:

Wybór mamki jest przy tym tak niezmiernie trudny, że podziwiać można odwagę tych matek, które swe dzieci powierzają nieznajomym kobietom, często nawet nie poddawszy ich gruntownej rewizji lekarskiej. Wreszcie, żeby była i najlepsza, osoba zupełnie obca nie może mieć dla dziecka tego poświęcenia, tego oddania, jakiego ono wymaga. Czyż można czym zastąpić troskliwość matki i to czułe pielęgnowanie, do którego ją karmienie nakłania przez ciągłe obcowanie z dzieckiem? (Jarosław 1885, s. 103)

Przestrzegano matki, że niewłaściwy wybór mamki może pociągnąć za sobą opłakane skutki - mamka mogła zarazić karmione dziecko; jeśli nie dbała o własną higienę, dziecko mogło również zachorować. Niektórzy publicyści twierdzili, że mamka mogła przekazać dziecku wraz z mlekiem swoje negatywne cechy, np. złośliwość, drażliwość, kłótliwość itp. Jeśli była osobą niemoralną, w przyszłości dziecko mogło zachowywać się niemoralnie (Pogadanka... 1901, s. 620; M.Dr. 1912, s. 99). Dlatego zachęcano matki, aby same karmiły piersią własne dzieci. Korespondent „Świtu” uznał to wręcz za obowiązek patriotyczny kobiet polskich, przypominając: „,...) w czasach świetności i blasku matki same karmiły i dobrze nam było, i byliśmy silni, zdrowi i szczęśliwi” (Jarosław 1885, s. 103). Niestety, w drugiej połowie XIX w. dość powszechnie uważano, że zatrudnianie mamki do dziecka jest wyznacznikiem wyższej pozycji społecznej rodziny.

Oczywiście niektóre kobiety ze względu na stan zdrowia nie mogły karmić piersią niemowlęcia. Zalecano im wówczas, aby zatrudniły zdrowe fizycznie i moralnie mamki. Zofia Czarnocka sądziła, że najlepsze są mamki wiejskie, jednak matka powinna mieć nad swym dzieckiem i jego karmicielką nieustanną pieczę (Czarnocka 1902, s. 82). Również w „Kronice Rodzinnej” zwracano uwagę na konieczność dobrego poznania przyszłej mamki:

Wybór kobiety na mamkę powinien być bardzo staranny, a przede wszystkim należy żądać bardzo szczegółowego zbadania mamki przez lekarza, aby się przekonać, czy jest zupełnie zdrowa. Niezbędnym jest też wymaganie świadectwa, że kobieta taka nie ulega nałogowi pijaństwa, nie jest złośnicą i w ogóle ma charakter łagodny (Jak wychowywać... 1906, s. 559). 
Eliza Orzeszkowa w książce Kilka stów o kobietach, opublikowanej w 1870 r. w „Tygodniku Mód i Nowości” (wydanie książkowe ukazało się trzy lata później), wypowiedziała się na temat żywienia dzieci nieco starszych. Podkreśliła, że nie mogą one jeść wszystkiego, co jedzą osoby dorosłe. Pożywienie dzieci powinno być dostosowane do wieku, bogate w składniki odżywcze i urozmaicone. Dziecko rośnie i rozwija się, nie powinno więc być karmione łakociami przy równoczesnym ograniczaniu ilości substancji niezbędnych do właściwego rozwoju. Publicystka sądziła, że najwięcej błędów popełniają matki w karmieniu córek. Chłopcy przeważnie otrzymują pożywienie proste, niewyszukane, natomiast już małym dziewczętom podawano wykwintne potrawy, ale niesłużące ich rozwojowi. Przy okazji uczono je grymaszenia, wybrzydzania, kształtowano niewłaściwy gust. A wszystko po to, aby w przyszłości znały smaki wyszukanych potraw, potrafiły wybrać je na przyjęcia i właściwie zachować się w towarzystwie podczas ich spożywania (Orzeszkowa 1874, s. 70).

Również G. Fritsche w „Bluszczu” wypowiadał się na temat sposobu odżywiania dzieci starszych:

(...) dzieciom dawać potrawy jak najpożywniejsze, złożone z mleka, jaj, mięsa smażonego, jarzyn, chleba z masłem lub innym zdrowym tłuszczem etc. Dzieciom zalecać należy, żeby dobrze żuły i śliniły potrawy, gdyż w ten sposób pomaga się trawieniu i wzmacnia zęby. (...) Tłuszcze, jak świeże surowe masło, tłuste mięso, pieczenie etc. są nieodzownie potrzebne dla dziecięcego ustroju (Fritsche 1880, s. 120).

\section{NADMIERNE STROJENIE CÓREK}

Następnym terenem, na którym rodzice popełniali wiele błędów wychowawczych, było ubieranie dzieci. Chłopców ubierano zazwyczaj odpowiednio do pogody, mieli zapewnioną dość dużą swobodę ruchów, pozwalano im brudzić ubranie i ciało. Od dziewczynek już od najmłodszych lat wymagano dbałości o strój, ubierano je wykwintnie, w ubranka szyte na wzór strojów dorosłych kobiet. Takie suknie przeważnie odznaczały się dużą ilością koronek, były szyte z delikatnego materiału, łatwo brudziły się lub ulegały zniszczeniu. Przeszkadzały więc w zabawie i ograniczały swobodę ruchów.

Jan Kanty Gregorowicz, wieloletni redaktor „Tygodnika Mód i Nowości”, a potem „Tygodnika Mód i Powieści”, podzielił się z czytelniczkami pisma refleksjami, jakie pojawiły się u niego podczas spaceru w Ogrodzie Saskim w Warszawie. Doszedł do wniosku, że lalkami bawią się nie tylko dzieci, ale również niektóre matki zachowują się tak, jak gdyby ich córki były lalkami, które można postawić w eksponowanym miejscu i z daleka podziwiać. Redaktor opisał wygląd i zachowanie dwóch dziewczynek, które spotkał w Ogrodzie: 
(...) dostrzegłem przy barierce zapatrzoną w ziemię jakąś dziewczynkę sześcioletnią, bardzo skromnie ubraną, ale czysto, starannie z buziaczkiem jak jabłuszko i ze wszystkimi cechami zdrowia i właściwie rozwiniętej siły.

Na ławce niedaleko siedziały dwie kobiety zajęte rozmową, a przy nich stała druga dziewczynka, ale przynajmniej o rok starsza, ubrana w białe kamaszki zapinane aż po kolana, w sukienkę z krynoliną, w płaszczyk także biały, z małą pelerynką, szczelnie opięty w pasie i wyłożony dokoła sztucznym barankiem. Szyję ozdabiał kołnierzyk, rączki mankietki bufiasto przyrządzone, a główkę okrywał okrągły biały kapelusik przystrojony piórami i woalką nader delikatną, okrywającą dwa warkoczyki zaplecione niebieskimi wstążkami. Twarz dziewczynki delikatna, biała, lekko rumieniąca się, cała postać zgrabna, ale niezmiernie wiotka, każde poruszenie ostrożne, jakby naprzód obmyślane i wyrachowane, choć miła dla oka, ale bardzo podobna do pięknej laleczki, o którą ciągle lękać się trzeba, aby nie uległa jakiemu wypadkowi, nie stłukła się, nie podarła lub nie rozbiła w kawałki (Janko z Bielca 1864, s. 4).

Sześciolatka „biegała, śmiała się, skakała, nachylała się, bo strój jej skromny i zupełnie zastosowany do wieku, żadnej nie czyniąc w ruchach przeszkody, dawał tyle dla dziecka upragnioną swobodę, która w zabawie, tej naturalnej gimnastyce dzieci, musiała wpłynąć na rozwój fizyczny całej budowy, a tym samym zdrowia i hartu ciała" (Janko z Bielca 1864, s. 5). Zupełnie inaczej zachowywała się dziewczynka siedmioletnia. Stała przy ławce, na której siedziała jej matka, i uważała, aby nie ubrudzić ubrania, z tęsknotą spoglądała na swobodnie bawiącą się koleżankę. I chociaż w pewnej chwili włączyła się do zabawy, to jednak „Strój wiecznie jej przeszkadzał, to się kapelusik skrzywił, to woalka zwiesiła, mankiety pomięły, to kamaszki wykręciły, to pelerynka zasłoniła, to krynolina zawadziła, dosyć że nie było prawie chwili, w której by dziewczątko nie miało z ubraniem kłopotu" (Janko z Bielca 1864, s. 5).

$\mathrm{Na}$ konieczność odpowiedniego do wieku ubierania dzieci zwróciła uwagę także Maria Ilnicka, wieloletnia redaktorka „Bluszczu”, która w jednym z artykułów poświęconych zabawie najmłodszych napisała:

Skrępować wśród takich chwil dziecko względami eleganckiej sukienki, odjąć mu dla tych względów swobodę rzeczywistą, obciążyć drugostronnie duszyczkę młodą złym ciężarem rozbudzonej próżności, wprowadzić w serce dziecka pychę lub zazdrość, odjąć mu przedwcześnie rajską nieświadomość różnic ludzi dzielących, jest nie tylko siać ziarno najgorsze w grunt dziecka moralny, ale dopuszczać się na nim okrucieństwa i niemiłosierdzia, skracając mu nielitościwie stan anielskiej błogości ducha, anielskiej nietroskliwości o dobra czy nędze ziemskie (Ilnicka 1878, s. 81).

Nadmierne strojenie dzieci krytykowano nawet w czasopismach poświęconych modzie. Jednym z nich są „Mody Paryskie”, gdzie w 1879 r. zamieszczono cykl artykułów pt. Dziewczynka i Sukienka. Ich autorka przestrzegała matki, że już u trzyletniej dziewczynki występuje tendencja do strojenia się w rzeczy jaskrawe, 
a swoje lalki z upodobaniem ubiera w każdą znalezioną szmatkę. Tymczasem bezmyślna matka „szyje, lub co gorsza przepatrzywszy najpierwsze magazyny, za drogie pieniądze kupuje różnobarwne sukienki, a każda zdobna guzikami, haftami, koronkami, kokardkami i tysiącem tych drobnych fatałaszków, które z dziewczynki robią małpeczkę przebraną w suknię dorosłej osoby" (Dziewczyn$k a \ldots .1879$, s. 1). Publicystka przekonuje, że takie stroje ograniczają dziecku ruchy, skupiają uwagę na własnej osobie, stają się powodem wynoszenia się ponad dzieci ubrane bardziej odpowiednio do wieku, utrudniają obserwację otaczającego świata poprzez ciągłe zwracanie uwagi na to, aby nie zniszczyć pięknych sukni (Dziewczynka... 1879, s. 1).

\section{BRAK TROSKI O ROZWÓJ FIZYCZNY DZIEWCZĄT}

Publicyści niejednokrotnie zachęcali rodziców do stwarzania dzieciom okazji do zabaw na świeżym powietrzu, krytykowali jednak odbywające się w Warszawie w ogrodzie zoologicznym publiczne zabawy dla dzieci. M. Ilnicka podkreśliła, że ogród ten jest zbyt mały na takie imprezy: „,...) nie daje dzieciom możliwości rozbiegnięcia się wśród przestrzeni otwartej, a przedstawia wadę ogromną złego powietrza, które sprowadza sąsiedztwo zwierzyńca, więc dla samych już względów higienicznych nie może być obranym na miejsce stale się powtarzającego i liczniejszego zbierania się tam dzieci" (Ilnicka 1886, s. 338). Ponadto tylko pewna grupa dzieci mogła wykonywać proponowane ćwiczenia gimnastyczne: „(...) reszta, niezajęta, nie mająca miejsca, aby się podzielić na grupy i oddać swobodnie jakimś grom wesołym, obraca się w kółko i przygląda sobie nawzajem, lustruje się i na odwrót, jest na tę lustrację wystawiona, co jej nie pozwala na potrzebną swobodę" (Ilnicka 1886, s. 338). Proponowała więc rodzicom wycieczki i spacery do Ogrodu Botanicznego, Łazienek, na Wierzbno, Mokotów. Sądziła, że będzie to zdrowsze i bardziej atrakcyjne dla dzieci.

Również E. Orzeszkowa zauważyła, że rodzice w zbyt małym stopniu troszczą się o rozwój fizyczny młodego pokolenia, a szczególnie córek. Dlatego domagała się:

Aby dziewczynka od pory, w której zaczyna chodzić o własnych siłach, posiadała zupełną swobodę ruchu do lat 7 lub 8, a potem aby godziny systematycznych i przywiązujących ją do miejsca nauk były dlań przeplatane godzinami przechadzki, gimnastyki, tańców, wszystkich słowem ćwiczeń wzmacniających i rozwijających ciało. Aby w oswajaniu dzieci ze zmianami temperatury, wychowujący nie czynili tak wielkiej jak dotąd różnicy pomiędzy dziećmi dwóch płci (...). Aby unikać wszystkiego, co może wzbudzić w dziewczynce nerwową, chorobliwą lękliwość, a rozwijać w niej przeciwnie jak największą odwagę fizyczną (Orzeszkowa 1874, s. 94-95).

Dr G. Fritsche na łamach „Bluszczu” zachęcał do hartowania dzieci. Proponowat: 
(...) ostrożne hartowanie ciała, do czego służą: zimne obmywanie, dłuższe przechadzki, pożywne potrawy, przebywanie na wolnym powietrzu, gra w piłkę, gimnastyka etc. oraz ostrożne ćwiczenia umysłu (uczenie się na pamięć drobnych wierszy lub opowiadań, ćwiczenia myśli etc.). Wszelkiego zmęczenia i nauki dłuższej nad godzinę trwającej unikać trzeba (Fritsche 1880, s. 120).

W stosunku do dzieci starszych i młodzieży do lat 16 zalecał oddziaływania profilaktyczne:

(...) nie pozwalając sypiać pod zbyt ciepłym przykryciem, unikając zbytniej troskliwości, marzącej bezczynności, nie pozwalając na grymasy, nie ulegając lada żądaniu dziecka. Dziecię należy wprawiać do panowania nad sobą, obchodzenia się bez przysmaków; potrzeby jednak dziecka powinny być w zupełności zaspokajane (Fritsche 1880, s. 128).

G. Fritsche zwracał też uwagę na rolę zabaw gimnastycznych i swobodnych ćwiczeń organizowanych w szkołach dla dziewcząt. Zabawy te „równoważyć powinny spokojne i siedzące życie domowe”, gdyż „nadają one zręczności ciału i przyczyniają się do jednostajnego krążenia krwi" (Fritsche 1880, s. 128). Powodują ponadto właściwy rozwój mięśni. Niestety - pisał - rodzice często zaniedbują rozwój fizyczny swych córek, a przecież systematyczny rozwój mięśni klatki piersiowej mógłby zapobiec „chorobom piersiowym”. Ćwiczenia fizyczne powinny być odpowiednio dobrane. G. Fritsche zalecał dziewczętom: ćwiczenia swobodne, pływanie, jazdę na łyżwach oraz większą dbałość o higienę szkolną i zapobieganie przeciążeniom nauką (Fritsche 1880, s. 128). Powyżej 16. roku życia zalecał położyć nacisk na rozwój samodzielności charakteru i samowychowanie:

Celem takiego wychowania powinna tu być dla młodzieńca: siła, odwaga i wytrwałość, a dla panienki: gospodarność, skromność, towarzyska uprzejmość i zręczność. Tak chłopcy, jak dziewczęta, powinny starać się o zamiłowanie porządku, punktualność, czystość, energię w działaniu, poznanie siebie, rozsądek w panowaniu nad sobą i osiągnięciu umysłowej swobody (Fritsche 1880, s. 136).

Również na łamach „Dobrej Gospodyni” nawoływano do większej troski o wychowanie fizyczne dziewcząt. Jedna z publicystek przekonywała czytelniczki, że „kobieta musi być zdrową i silną, aby istoty, którym daje życie, były zdrowe i silne" (Fizyczne wychowanie... 1911, s. 98). Za główne składniki wychowania fizycznego uznała: powietrze, przestrzeń i ruch. Zalecała zachęcanie dziewcząt do ruchu, gdyż - jak zauważyła - już od najmłodszych lat są one krępowane w tym względzie przez ,usposobienie, wychowanie, rodzaj zajęć, fałszywe pojęcie przyzwoitości i estetyki" (Fizyczne wychowanie... 1911, s. 98). Publicystka proponowała dziewczętom ćwiczenia rozwijające klatkę piersiową (gdyż chronią 
przed chorobami płuc) oraz brzucha (umożliwiają zachowanie właściwej sylwetki, nawet pomimo kilkakrotnego macierzyństwa). Pisała:

Ćwiczenia fizyczne, dające zdrowie i siły kobiecie, nie powinny psuć harmonii jej kształtów, powinny je raczej doskonalić i poprawiać, i dlatego unikać należy ćwiczeń, wyrabiających niepomiernie mięśnie rąk, wywołujących zaokrąglenie pleców, wzniesienie ramion, natomiast wybierać te, które poprawiają postawę, dają pewność ruchów, zręczność, zwinność i wytrzymałość (Fizyczne wychowanie... 1911, s. 98).

\section{PRZECIĄŻENIE NAUKĄ I JEGO SKUTKI}

Młode dziewczęta w drugiej połowie XIX i na początku XX w. na terenach zaboru rosyjskiego i pruskiego nie miały możliwości podjęcia studiów wyższych. Jedynie w zaborze austriackim funkcjonowały dwa polskie uniwersytety, jednak i tam dostęp dla kobiet był ograniczony (Pachucka 1909, s. 434; Wójcicka-Chylewska 1909, s. 1). Dlatego wiele dziewcząt wyjeżdżało na studia za granicę. Ponieważ znaczna część kandydatek na studentki kończyła prywatne pensje żeńskie lub uczyła się w domu, nie posiadały one wystarczającego przygotowania na poziomie szkoły średniej do podjęcia studiów wyższych. Po rozpoczęciu studiów, widząc swoje braki, kosztem nadmiernego wysiłku i przemęczenia usiłowały nadrobić materiał z zakresu gimnazjum, a jednocześnie na bieżąco kontynuować studia. S. Górski pisał, że studentki takie „często nie rozumieją należycie wykładu, a profesorowie z konieczności muszą obniżać poziom prelekcji” (Górski 1904, s. 481). Było to bardzo trudne nie tylko dla dziewcząt, ale też dla pracowników wyższych uczelni, gdyż obniżanie poziomu wykładów dyskredytowało opinię uczelni (Górski 1906, s. 249). Ponadto część studentek nie posiadała wystarczających środków materialnych na utrzymanie się poza domem, więc dodatkowo do zmęczenia dochodziło wycieńczenie fizyczne. Czasami taka nadmierna praca kończyła się śmiercią studentki, częściej jednak porzucały one studia, a czasami wracały do domu „ze zwichniętym życiem” (A. Gr. 1890, s. 321). Dlatego przestrzegano dziewczęta mające zamiar udać się na zagraniczną uczelnię:

Jedyna tu rada - przygotować się na miejscu, w domu, gdzie warunki materialne łatwiejsze, lekcje tańsze. A program tego, co potrzeba łatwo można sprowadzić z Paryża, gdzie istnieją podręczniki streszczające wszystko, czego wymaga się do egzaminu bakałarskiego. W przeciwnym razie uniwersyteckie studia kobiet zawsze będą miały cechę dyletantyzmu, a w poszukiwaniach samodzielnych, jeżeli takowym zechcą się oddać - będzie się im dawał czuć brak podstawowych wiadomości (m...a 1885, s. 181).

Aby zapobiec takim sytuacjom, doradzano rodzicom, by zadbali o jak najlepsze przygotowanie córek w zakresie szkoły średniej. Dziewczęta nie powinny 
wyjeżdżać, jeśli nie posiadały wystarczających środków na utrzymanie i zamierzały zarobić, pracując i jednocześnie studiując (Dla tych ... 1909, s. 311). Niektóre nie posiadały wystarczających zdolności i w tym przypadku rodzice powinni poradzić im raczej wybór jakiejś szkoły gospodarczej, po której mogły zarządzać własnym gospodarstwem lub podjąć pracę w bardziej zamożnych rodzinach (N.J. 1908, s. 169).

\section{BRAKI W ZAKRESIE PRZYGOTOWANIA DZIEWCZĄT DO MAŁŻEŃSTWA}

Problematyka ta pojawiła się w omawianych czasopismach już w latach 70 . XIX w., jednak wówczas skupiano się głównie na zagadnieniach z zakresu przygotowania dziewcząt do obowiązków rodzinnych, prowadzenia gospodarstwa domowego i wspierania męża $\mathrm{w}$ jego troskach związanych $\mathrm{z}$ utrzymaniem rodziny. Rodzice, dążąc do dobra własnych córek, niejednokrotnie popełniali w ich wychowaniu poważne błędy. E. Orzeszkowa krytykowała rodziców, którzy od najmłodszych lat wpajali córce, że ,stworzona jest, aby być żoną, matką, gospodynią" (Orzeszkowa 1874, s. 18), powinna więc poświęcać się dla innych, zapomnieć o swoich potrzebach. W latach 70. XIX w. niemal każda młoda dziewczyna uważała małżeństwo za pełne, niekończące się szczęście, natomiast nie znały czekających je obowiązków, nie potrafiły też przewidzieć przyszłych przeszkód i przeciwności życiowych (Orzeszkowa 1874, s. 18-20). Orzeszkowa przestrzegała, że nie wszystkie dziewczęta wyjdą za mąż, zaś „Pozbawione rodzinnego życia, nie umiejąc wybrać sobie żadnego celu ani mogąc rozmiłować się w żadnym, czują w sobie samych próżnię, której nie mają czym zapełnić" (Orzeszkowa 1874, s. 45). Stara panna stawała się niejednokrotnie przedmiotem żartów i kpin, przypisywano jej wiele cech negatywnych. Orzeszkowa sądziła, że ich czasami śmieszne zachowania wynikają z braku celu w życiu. Gdyby mogły zająć się jakimś pożytecznym zajęciem, rozwijać swoje pasje i zainteresowania, niewątpliwie ich życie wyglądałoby inaczej.

A gdyby ten młyn duchowy znalazł w głowie kobiety myśl zdrową i oświeconą, wiedzę, znajomość społeczeństwa i jego potrzeb, miłość dla pięknej jakiej idei, pragnienie czynu i umiejętność pracowania, wytworzyłby zapewne (...) zamiast śmiesznego pożyteczne, zamiast złośliwego zbawienne, zamiast występnego cnotliwe życie (Orzeszkowa 1874, s. 45).

Nieroztropni rodzice nie przyczyniali się również do szczęścia córek zamężnych, których małżeństwo nie spełniło wygórowanych oczekiwań i pragnień. Zawiedziona w swych nadziejach kobieta przez resztę życia była „nieszczęśliwą istotą, chorą na ciele i duchu, zwiedzioną, rozczarowaną, nie zrozumianą przez świat i świata nie rozumiejącą”, skazaną na to, aby „wyrzekać, chorować, nudzić 
się, szukać pociechy i rozrywki w próżnych, a rujnujących moralnie i materialnie połyskach", przyczyniając się jednocześnie do rozpowszechniania w społeczeństwie poglądu, że „kobieta ani gruntownie myśleć, ani pożytecznie działać nie jest zdolną" (Orzeszkowa 1874, s. 32).

Kwestie uświadamiania seksualnego młodych kobiet $\mathrm{z}$ trudem torowały sobie drogę na łamach omawianych czasopism. Pojawiają się częściej dopiero po 1900 r., chociaż i wówczas spotykały się ze zróżnicowaną oceną czytelniczek. Starsze kobiety wyrażały obawę, czy uświadamianie dorastającej dziewczynie jej przyszłych obowiązków małżeńskich nie przyczyni się do utraty przez nią niewinności. Przedstawicielki młodszego pokolenia domagały się, aby każda młoda dziewczyna, a zwłaszcza będąca narzeczoną, miała wiedzę dotyczącą przyszłych obowiązków małżeńskich oraz by umiała ustrzec się przed ewentualnymi zagrożeniami (zwłaszcza chorobami). Jednak postulaty te przeważnie nie były formułowane wprost, raczej przybierały postać sugestii lub pytań retorycznych. Redakcje czasopism, utrzymujące się z opłat prenumeratorek, wśród których było niewątpliwie dość dużo przedstawicielek starszego pokolenia, nie mogły zgodzić się na publikację zbyt śmiałych wypowiedzi czytelniczek. Dlatego w odpowiedzi na list „Jednej z matek”, która twierdziła, że sama zachowała zupełną nieświadomość i niewinność aż do dnia ślubu, J. Bąkowska pisała:

Zachowanie „całkowitej naiwności” do dwudziestego roku życia wydaje mi się faktem zupełnie wyjątkowym, w ogóle w życiu tak nie bywa; jako też „,chowanie prawdy przez matki aż do dnia ślubu córki” jest, moim zdaniem, wprost błędnym. Jak to? Więc panna dorosła nie ma wiedzieć, gdzie, dokąd idzie i wykonywać sakramentalną przysięgę na coś, czego nie zna? Więc podejmuje się obowiązków wobec człowieka, obowiązków nierozerwalnych, a nie wie, jakie one będą, czy im podoła, tylko tak leci w przyszłość na oślep, bez żadnego sumiennego przygotowania się do nowego życia? To by było przecież nieuczciwie tak iść za mąż. A przecież w jednej godzinie przed ślubem matka jej nie przygotuje? Zresztą nie myślmy, nie wyobrażajmy sobie tego wcale, że uświadamianie trzymamy sobie despotycznie w rękach, damy albo go nie damy, a młoda dusza pokornie czeka naszego objawienia. Gdzież tam! dusza żyje, rozwija się, uświadamia przede wszystkim własną swą wewnętrzną mocą (...). Dlatego też sądzę, że „trzymać duszę swego dziecka jak lilijkę w ręku" można tylko do jakich lat 3-5 najwyżej, później rozpoczyna się już wyrabianie wewnętrznego materiału, któremu nie jesteśmy w stanie czegoś ani narzucić, ani zakazać tym bardziej (Szczęsna 1904, s. 219).

\section{Publicystka radziła więc matkom:}

Małe dziecko do jakich lat nawet dziesięciu zostawmy w błogim jego stanie niewiadomości, dajmy mu „święty” spokój; ale gdy młodość motylich dostaje skrzydeł i rwie się do lotu, żądna przestrzeni, obszarów i swobody ruchu - nie zaprzeczajmy jej prawa dążenia, dowiadywania się, strzeżmy od ognia, lecz nie krępujmy dojrzewających w słońcu skrzydeł (Szczęsna 1904, s. 220). 
Czytelniczka, podpisująca się jako „Jedna z panien”, również wyraziła swoje zdziwienie i oburzenie w związku z ukrywaniem przed młodymi kobietami prawdy o ich obowiązkach małżeńskich:

O poważnych obowiązkach, jakie ma pełnić z chwilą zamążpójścia, o tym, iż ma zostać matką, rozumną i odpowiedzialną wychowawczynią i pedagogiem - wiedzieć kobiecie nie wolno! (...) W ten sposób kobieta bywa narażona na straszne dramaty, z chwilą gdy życie nieznane, tak inne od mglistej atmosfery poezji, w jaką ją spowito, stanie jej naraz brutalnie przed oczyma. Kontrast bywa zbyt silny. Nie nauczona, czym jest małżeństwo i nie znająca zupełnie człowieka, którego z chwilą ślubu osoba jej i majątek staje się własnością, spostrzega nagle przed sobą przepaść - nieszczęście, które niepowrotnie łamie jej życie. A tego można uniknąć tylko przez rozumne, jawne i poważne traktowanie rzeczy. (...) Nie dosyć jednak na tym. Poza osobistym nieszczęściem danego osobnika, mamy jeszcze do czynienia z kwestią daleko ważniejszą, lekceważoną tak bezmyślnie przez niesumiennych wychowawców - kwestią doniosłej odpowiedzialności moralnej za karygodne bezmyślne zaciąganie obowiązków względem przyszłego pokolenia - obowiązków, do spełnienia których nie posiada się elementarnych nawet kwalifikacji. (...) Miejmy więc zawsze na uwadze, że prawda bezwzględna, szczerość i jawność muszą być zasadami życia i każdej uczciwej działalności, a zatem przede wszystkim i wychowania. Że tylko z prawdy pochodzą zacne i dobre czyny (Jedna z panien... 1904, s. 74).

Czasami jednak w „Dobrej Gospodyni” pojawiały się artykuły, których autorki wprost domagały się uświadamiania seksualnego dziewcząt. Podkreślały, że jest to rola matki, która powinna wyjaśnić córce zagrożenia związane z tą dziedziną życia. Jednocześnie rodzice, a zwłaszcza ojciec, powinni starać się poznać przeszłość kandydata na zięcia, zdobyć informacje o sposobie jego prowadzenia się, aby uchronić córkę przed wieloma chorobami roznoszonymi drogą płciową. Przekonywano rodziców, że nie jest dobrym kandydatem na męża ten, który przez kilka lat zdążył się „wyszumieć”. Domagano się zarówno od chłopców, jak i od dziewcząt dbania o czystość moralną, gdyż jest to gwarantem zdrowia przyszłych pokoleń i samych rodziców. Zwracano uwagę matkom, że ich dorośli synowie nie mają prawa do korzystania z usług prostytutek i jednocześnie oczekiwania, że ich przyszła żona będzie dziewicą. Z. Bielicka podkreśliła, że rodzice zupełnie bezmyślnie godzą się ze złem i nie robią niczego, aby mu przeciwdziałać (Bielicka 1904, s. 347). Orzeszkowa zaś krytykowała rodziców, którzy narzucali córkom kandydatów na mężów. Przekonywała, że młodzi powinni się poznać i dopiero potem zdecydować na wspólne życie. Podstawą udanych związków małżeńskich jest miłość i wzajemny szacunek, a trudno o nie w sytuacji, gdy mąż jest narzucony, a za córkę podejmują decyzję jej rodzice, kierujący się przede wszystkim względami materialnymi. Publicystka przekonywała czytelniczki, że tylko małżeństwo oparte na wzajemnym poznaniu, miłości i szacunku, wspólnej pracy, dążeniach i wartościach może być szczęśliwe (Orzeszkowa 1874, s. 212). 


\section{ZAKOŃCZENIE}

Podstawowym warunkiem dobrego funkcjonowania człowieka i wypełniania stawianych przed nim zadań jest jego właściwy rozwój fizyczny. Podstawy tego rozwoju sięgają okresu wczesnego dzieciństwa, w którym na małego człowieka czyha wiele niebezpieczeństw. Zadaniem rodziców jest zapobieganie sytuacjom zagrażającym zdrowiu i życiu własnego potomstwa. Czasami jednak ich postępowaniem kierują inne względy: społeczne, kulturowe, obyczajowe. Oczywiście nie muszą być sprzeczne ze zdrowym rozsądkiem i wiedzą dotyczącą prawidłowości rozwojowych dzieci i młodzieży. Zdarza się jednak, że rodzice, mając przede wszystkim na uwadze opinię społeczną, postępują wbrew własnemu rozsądkowi i zaleceniom specjalistów. Taka sytuacja miała miejsce w XIX w., gdy wychowanie dziewcząt i chłopców różnicowano ze względu na ich przyszłe obowiązki. Dobrze oddaje je wypowiedź Orzeszkowej zamieszczona w książce Kilka słów o kobietach. Chłopcom od najmłodszych lat wpajano przekonanie:

Będziesz mężczyzną - a więc ucz się być wytrwałym na chłód i na głód, strzeż się skarg i łez, bo one ci nie przystoją, używaj co najwięcej fizycznych ćwiczeń, aby jak najlepiej rozwinąć siłę ciała, bądź poufałym ze zwierzętami i palną bronią, nabieraj słowem co najwięcej hartu i wytrzymałości, gdyż cnotą twoją ma być odwaga - ozdobą siła (Orzeszkowa 1874, s. 69).

Dziewczynkę zaś wychowywano według zasady:

Będziesz kobietą: staraj się więc siedzieć najciszej w najcieplejszym kąciku, unikaj tchnienia wiatru lub promienia słońca, trzymaj się prosto, mów cichuteńko, przechadzaj się powoli, spożywaj słodycze, roń łzy przy każdej wydarzonej sposobności, z krzykiem przestrachu uciekaj od zwierząt, mdlej z obawy na widok broni palnej, gdyż cnotą twoją ma być nieśmiałość - ozdobą słabość i łzy (Orzeszkowa 1874, s. 69).

Różnice w wychowaniu niewątpliwie odbijały się na kondycji fizycznej dzieci obu płci. Szczególnie zaniedbane były pod tym względem dziewczęta. Dlatego publicyści przekonywali rodziców, że zarówno wychowanie chłopców, jak i dziewcząt powinno obejmować harmonijny rozwój sfery fizycznej, umysłowej i moralnej, którym odpowiadają ciało, umysł i serce. Orzeszkowa twierdziła, że „zwichnięcie lub niedołężność jednej z tych władz osłabia i krzywi lub unicestwia dwie inne" (Orzeszkowa 1874, s. 51). Z tego powodu postulowała konieczność zadbania o prawidłowy rozwój fizyczny i zdrowie dziewcząt, zapewnienie im odpowiedniego wykształcenia ogólnego i zawodowego oraz zatroszczenie się o ich rozwój moralny. Ubolewała, że:

(...) w wychowaniu naszych kobiet, oprócz nielicznych wyjątków, strona fizyczna jest w zaniedbaniu zupełnym, umysłowa skrzywiona, niedostateczna i dla błahych, a zgubnych rozwijana 
celów, moralna piastowana wprawdzie troskliwie, gorliwie apostołowana, lecz wskutek słabości fizycznej i umysłowej nie przynosząca bynajmniej pożądanych owoców (Orzeszkowa 1874, s. 64).

Pomimo słuszności postulatów publicystów z drugiej połowy XIX i początku $\mathrm{XX}$ w., dotyczących konieczności zmiany podejścia do wychowania dziewcząt, minęło jeszcze wiele lat zanim troska o wszechstronny rozwój dzieci, bez względu na ich płeć, stała się rzeczywistością. Opinie publicystów omawianego okresu stały się niewątpliwie „kroplą drążącą skałę”. Dzięki nim dostrzeżono problem i podjęto próby jego rozwiązania. Chociaż żyjemy w innych uwarunkowaniach społeczno-politycznych i gospodarczych, warto zapoznać się z poglądami publicystów przełomu XIX i XX w., zajmujących się tak ważną kwestią społeczną, jaką jest wychowanie dziewcząt.

\section{BIBLIOGRAFIA}

A. Gr. (1890), Środki i sity, „Kronika Rodzinna”, nr 11.

Bielicka Z. (1904), Kilka słów o uświadomieniu rodziców, „Dobra Gospodyni”, nr 42.

Czarnocka Z. (1902), Pogadanki z dziedziny wychowania, „Dobra Gospodyni”, nr 11.

Dla tych, co jada na uniwersytet (1909), „Bluszcz”, nr 28.

Dziewczynka i Sukienka (1879), „Mody Paryskie”, nr 6.

Fizyczne wychowanie kobiet (1911), „Dobra Gospodyni”, nr 13.

Fritsche G. (1880), Wiadomości z medycyny popularnej, „Bluszcz”, nr 15.

Górski S. (1904), Studentki w Galicji, „Bluszcz”, nr 41.

Górski S. (1906), Wyższe kursy żeńskie w Warszawie, „Bluszcz”, nr 22.

Janko z Bielca [J.K. Gregorowicz] (1864), Felieton, „Tygodnik Mód i Nowości”, nr 12.

Ilnicka M. (1878), Zabawa i wychowanie, „Bluszcz”, nr 11.

Ilnicka M. (1886), Zabawy dzieci w Zoologicznym Ogrodzie warszawskim, „Bluszcz”, nr 43.

Jak wychowywać dzieci (1906), „Kronika Rodzinna”, nr 47.

Jarosław (1885), Z listów do „Świtu”, „Świt”, nr 53.

Jedna z panien. W sprawie tak zwanego „, uświadamiania” młodzieży (1904), „Dobra Gospodyni”, nr 10. m...a (1885), W Sorbonie, ,Świt”, nr 63.

M. Dr. (1912), Karmienie niemowląt, „Dobra Gospodyni”, nr 13.

N.J. (1908), Wyższa szkoła gospodarstwa domowego, „Bluszcz”, nr 15.

Orzeszkowa E. (1874), Kilka słów o kobietach, Warszawa: Księgarnia C. Lewickiego i Spółki.

Pachucka R. (1909), Co mówiono na Zjeździe w Zakopanem o studentkach, „Bluszcz”, nr 39.

Pogadanka pod adresem mtodych matek (1901), „Dobra Gospodyni”, nr 52.

Szczęsna [J. Bąkowska] (1904), W sprawie uświadamiania młodzieży, „Dobra Gospodyni”, nr 27.

Wiadomości z medycyny popularnej (1880), „Bluszcz”, nr 13, 15, 16, 17.

Wójcicka-Chylewska Z. (1909), Studentki lwowskie, „Tygodnik Mód i Powieści”, nr 2. 


\section{SUMMARY}

Health is the basic right of a man. Care for proper development of seed lies with parents. They provide food to the child, care of proper outfit, organise its leisure time. They give specified principles and beliefs concerning health to the son and daughter. In the second half of $19^{\text {th }}$ century in lots of middle-income families were governed by convenance and public opinion rather in these items than reliable knowledge and common sense. Parents took improper attitude, especially towards their daughters. That was why publicists of journals were criticising that improper attitude to bringing up girls - the future mothers - out of concern of their health. To get knowledge of publicist opinions on mistakes made by parents against their daughter's bringing, the author of this paper held library queries with several journals including: "Bluszcz", "Tygodnik Mód i Powieści”, "Dobra Gospodyni”. The authors of the studied releases were not only focused on criticising the improper behaviours, but they also showed tips, guides what to do to reinforce right development of girls.

Keywords: bringing up of girls at the turn of the $19^{\text {th }}$ and $20^{\text {th }}$ century; upbringing mistakes made by parents; the normal physical development of girls 